Research paper

\title{
Production and quality analysis of pellets manufactured from five potential energy crops in the Northern Region of Costa Rica
}

\author{
Stephanie Aragón-Garita a , Roger Moya ${ }^{\mathrm{a}}{ }^{*}$, Brian Bond ${ }^{\mathrm{b}}$, Jorre Valaert ${ }^{\mathrm{c}}$, \\ Mario Tomazello Filho ${ }^{\mathrm{d}}$ \\ a Instituto Tecnológico de Costa Rica, Escuela de Ingeniería Forestal, P.O. Box: 159-7050, Cartago, Costa Rica \\ ${ }^{\mathrm{b}}$ Department of Sustainable Biomaterials, Virginia Tech, Blacksburg, VA, USA \\ ${ }^{c}$ Agrep Forestal S. A., Costa Rica \\ d Departamento de Ciências Florestais, ESALQ/Universidade de São Paulo, Av. Pádua Dias, 11-Caixa Postal 09, CEP 13418-900, Piracicaba, São Paulo, Brazil
}

\section{A R T I C L E I N F O}

\section{Article history:}

Received 23 September 2014

Received in revised form

5 February 2016

Accepted 9 February 2016

Available online 3 March 2016

\section{Keywords:}

Biomass

Residues

Lignocellulose crops

Short rotation crops

\begin{abstract}
A B S T R A C T
Modifications to a pellet manufacturing process must be made based on the characteristics of raw material used. The purpose of this work was to determine the alternations required to a wood pellet manufacturing process and the quality of the pellets produced using this process from five energy crops. Quality measurements include: the caloric value, the loss of moisture content in each production stage, the efficiency index of particle-pellet, ash content and quality as defined using the quantity of cracks and the transversal density and longitudinal density determined using X-ray radiography. The crops analyzed were rhizomatous plants, with caloric values ranging between 17.1 and $20.3 \mathrm{MJ} \mathrm{kg}^{-1}$. This work determined that it was possible to produce pellets with Gynerium sagittatum and Phyllostachys aurea using the same production process for wood; however, Arundo donax and Pennisetum purpureum needed pre-airdrying and the Sorghum bicolor required mechanical dewatering before drying. A. donax, P. purpureum and G. sagittatum provided the highest efficiency index. When evaluating the pellet quality $P$. aurea and G. sagittatum hard a large quantity of cracks, unlike A. donax, P. purpureum and S. bicolor. The transversal and longitudinal pellet density varied from 1129 to $1294 \mathrm{~kg} \mathrm{~m}^{-3}$. The highest values of bulk density were obtained in A. donax and P. purpureum, followed by G. sagittatum and P. aurea, and the lowest bulk density was obtained in S. bicolor. Althogh out, some species produced cracks and high ash content, this work demonstrated that it is possible to produce pellets with moderate quality.
\end{abstract}

(c) 2016 Elsevier Ltd. All rights reserved.

\section{Introduction}

Tropical conditions in Costa Rica allow the development of many agricultural and forestry crops, which generate a large amount of lignocellulosic waste [1]. For example, the agricultural sector produces approximately 1.5 million $\mathrm{Mg}$ of residues per year [2] the forest industry generates about $500,000 \mathrm{Mg}$ of residues [3] and this estimate does not consider the $43 \%$ of tree volume that remains in the field as residue [4]. The forest industry has been concerned with finding solutions to the residue problem and one possible solution is to generate heat by direct combustion of the raw residue [5]. Manufacturing residues into pellets is of interest to

\footnotetext{
* Corresponding author.

E-mail addresses: rmoya@itcr.ac.cr (R. Moya), bbond@vt.edu (B. Bond), jorre@ agrepforestal.com (J. Valaert), mtomazel@usp.br (M. Tomazello Filho).
}

these industries since the pellets would allow for better utilization of the material. Pellets could provide the heat for other processes, such as drying of fruits and vegetables, cooking or cleaning products [2].

Wood pellets are manufactured by a mechanical process, where pressure is applied to crush the cell structure and increase its density [6]. The normal process of producing wood pellets consists of: (i) using grinders and mills (discs, rollers, balls, blades or hammers) to reduce the size of the material, (ii) drying the biomass with rotary drum or pneumatic type driers to a $10 \%$ moisture content and (iii) compressing the material using rotary rollers, which pushes the particles from the inside of a ring or die (cylindrical or annular type or flat matrix) outwardly through a series of holes $[7,8]$, a technology commonly used to produce animal feed. While pellets can be made from wood, the high demand for wood residues in fiberboard and particleboard production represents direct competition for pellet industries in Costa Rica [5]. There are 
two important aspects regarding the use of wood residues in Costa Rica: (i) a tendency to reduce wood consumption in industry [9] and (ii) the residues produced are in high demand to keep chicken, horse and cattle breeding sites clean [5]. Pellet industries are therefore seeking an alternative raw material with high lignocellulosic content, such as agro-residues, or the cultivation of energy crops that can be densified [8]. Agricultural residues are currently in high demand as a supplement for animal feed concentrate $[10,11]$ or to produce organic compost products [12].

The use of agricultural or sawmill residues for pellet production is highly developed in many countries [7]. Pellets are as efficient as other fuels in boilers [13]. For pellet production to be economically viable, the raw material is processed with moisture content less than 55\% [14]. One limiting factor to using energy crops for pellet manufacturing is that many have initial moisture contents above $50 \%$, have lower hardness values, and smaller sizes than wood residue [15]. For the industry to be profitable manufacturing pellets from different types of biomass, such as the energy crops, with different morphology and moisture content, the process needs modification [1]. For example, air-drying the raw material in areas with appropriate environmental conditions [16] would result in more cost-effective production [17].

With knowledge of these constraints, the objective of the present work is to define the alterations in a wood pellet production process that would allow the use of five potential energy crops (Arundo donax, Gynerium sagittatum, Pennisetum purpureum, Phyllostachys aurea, and Sorghum bicolor) in Costa Rica. Specifically, the authors investigated the caloric value, the particle size prior to pelletizing, process efficiency, moisture content in each stage of the pellet production and quality (ash content, transversal density and longitudinal density) of the pellets by X-ray spectrometry. Quality measurements include: the caloric value, the loss of moisture content in each production stage and the efficiency index of particle-pellet, quality, transversal density and longitudinal density of the pellets through X-ray radiography.

\section{Materials and methods}

\subsection{Selected crops}

Five energy crops were selected for use in Costa Rica (Fig. 1 and
Table 1) based on the following constraints: adaptation to climatic and edaphic conditions of this country, dry biomass production above $20 \mathrm{Mg} \mathrm{ha}^{-1}$ and availability throughout the year. The five selected crops are perennial, with straight stems ranging from 2 to $6 \mathrm{~m}$ high and diameters from 1 to $5 \mathrm{~cm}$ (Fig. 1). G. sagittatum, $P$. aurea, and S. bicolor samples were harvested and transported to the plant located in San Carlos in one day and the pellets were prepared the next morning. For A. donax and P. purpureum material was left in the field where it was cut, and allowed to dry to decrease moisture content for three day (see 2.3.1).

\subsection{Crop characterization}

The characterization of each crop was based on the evaluation of the caloric value in the wet condition (after harvest, named Gross Caloric Value), the dry condition ( $0 \%$ moisture content, Net Caloric Value) and the ash content of the pellet produced. For these analyses, 3 stalks were randomly selected, cut and then milled to less than $2 \mathrm{~mm}$ and then sieved with \#60 and \#40 meshes $(0.25 \mathrm{~mm}$ and $0.42 \mathrm{~mm}$ respectively). The material between \#60 and \#40, mesh was selected and 3 , approximately $1 \mathrm{~g}$, samples were extracted. This material was then divided in two parts of $0.5 \mathrm{~g}$ each. A sample with the moisture content at the time of harvesting was used to determine the Gross Caloric Value (GCV); the second sample was kiln-dried at $103{ }^{\circ} \mathrm{C}$ for $24 \mathrm{~h}$, and then the net caloric value (NCV) was determined using ASTM D-5865 [18]. Net and gross caloric values were determined using Parr calorimetric test. Carbon fraction $(\mathrm{C})$, Nitrogen content $(\mathrm{N})$ and the $\mathrm{C} / \mathrm{N}$ relationship were determined from milled dust using Elementar Analysensysteme, Vario Macro Cube model. The material was sieved through $0.25 \mathrm{~mm}$ and $0.42 \mathrm{~mm}$ meshes (40-60 meshes respectively), until approximately $8 \mathrm{~g}$ per test were obtained.

\subsection{Crop evaluation in the production process}

Six aspects were considered in the evaluation of potential energy crops in Costa Rica: (i) adaptation of the crop to a wood pellet production process; (ii) net caloric values, (iii) loss of moisture content during the pellet production; (iv) characteristics of the produced particles; ( $\mathrm{v}$ ) efficiency in the process and (vi) pellet quality.

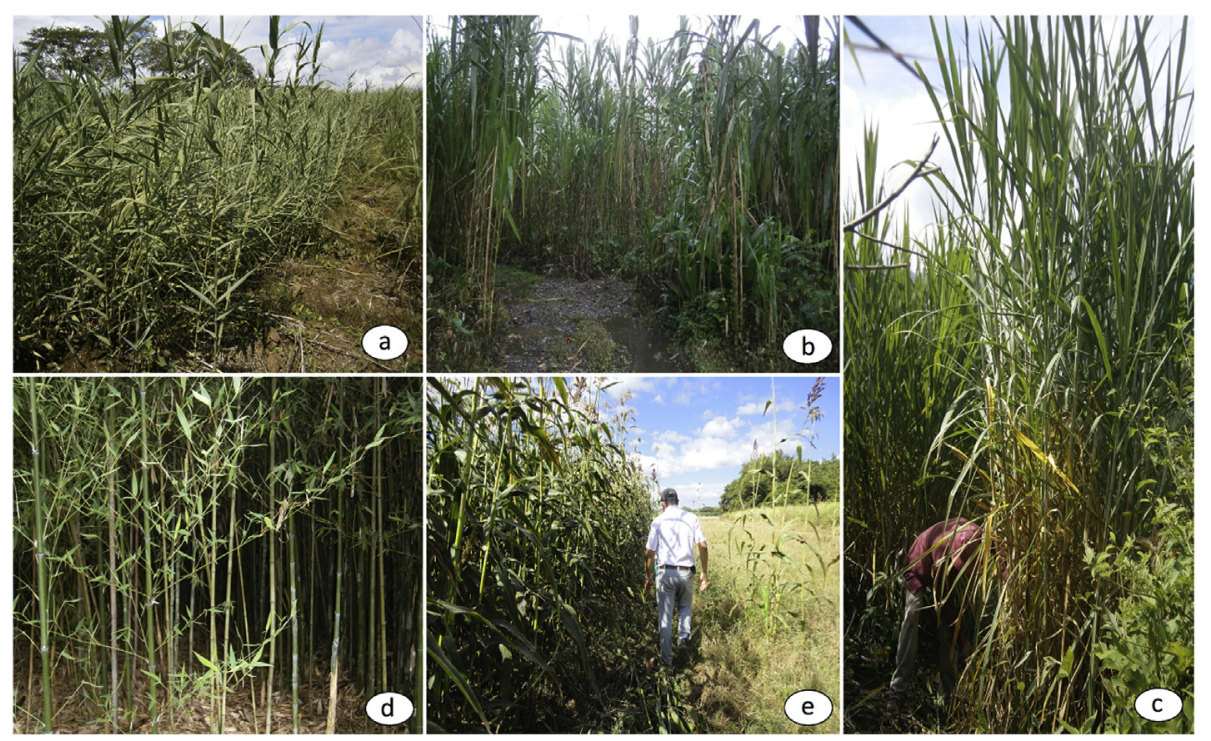

Fig. 1. Agricultural crops with energetic potential in Costa Rica. a) Arundo donax b) Gynerium sagittatum c) Pennisetum purpureum d) Phyllostachys aurea e) Sorghum bicolor. 
Table 1

Geographic location and information on the state of the five energy crops evaluated.

\begin{tabular}{|c|c|}
\hline Crop & Description of the crop site \\
\hline Arundo donax & $\begin{array}{l}\text { It is a rhizomatous plants belonging to the sigmoidal group (Fig. } 1 \mathrm{a} \text { ) and was planted in } 1.6 \mathrm{~m} \text { spaced rows (Fig. } 1 \mathrm{a} \text { ). The plantation yielded } 25 \mathrm{Mg} / \mathrm{ha}- \\
\text { year of dry biomass. This is a } 6 \text { month old experimental trial in Filadelfia, Guanacaste }\left(10^{\circ} 23^{\prime} 35^{\prime \prime} \text { latitude } \mathrm{N} \text { and } 85^{\circ} 27^{\prime} 49^{\prime \prime} \text { longitude W) and it was }\right. \\
\text { harvested on January of } 2013 \text { and it was sampled all stem and leaves. Each plant has } 5-6 \text { stems. }\end{array}$ \\
\hline $\begin{array}{l}\text { Gynerium } \\
\quad \text { sagittatum }\end{array}$ & $\begin{array}{l}\text { It is a rhizomatous plants belonging to the monopodial group (Fig. } 1 \mathrm{~b} \text { ). Commercial plantation for extracting poles for agriculture and construction } \\
\text { (Fig. } 1 \text { b), about } 15,000 \text { plants ha }{ }^{-1} \text { are produced, which yield about } 22 \mathrm{Mg} / \text { ha-year of dry biomass. } 1 \text {-year old, located in Río Frío, Limón ( } 10^{\circ} 18^{\prime} 38^{\prime \prime} \\
\text { latitude } \mathrm{N} \text { and } 83^{\circ} 52^{\prime} 58^{\prime \prime} \text { longitude W). It was harvested on February of } 2013 \text { and it was sampled all stem and leaves. Each plant has only one stem. }\end{array}$ \\
\hline $\begin{array}{l}\text { Pennisetum } \\
\text { purpureum }\end{array}$ & $\begin{array}{l}\text { It is a rhizomatous plants belonging to the sigmoidal group (Fig. 1c). Naturally growing trial approximately } 7 \text { months old (Fig. } 1 \mathrm{c}) \text { in Paraíso, Cartago } \\
\left(9^{\circ} 49^{\prime} 44^{\prime \prime} \text { latitude } \mathrm{N} \text { and } 83^{\circ} 51^{\prime} 6^{\prime \prime} \text { longitude } \mathrm{W}\right) \text {. It yielded } 31 \mathrm{Mg} \mathrm{ha}{ }^{-1} \text { year dry biomass. It was harvested on February of } 2013 \text { and it was sampled all } \\
\text { stem and leaves. Each plant has } 5-6 \text { stems. }\end{array}$ \\
\hline Phyllostachys aurea & $\begin{array}{l}\text { It is a rhizomatous plants belonging to the monopodial group (Fig. } 1 \mathrm{~d} \text { ). Crop planted in a small area of the Central Campus of the Costa Rica Institute of } \\
\text { Technology in Cartago }\left(9^{\circ} 51^{\prime} 08^{\prime \prime} \text { Latitude } \mathrm{N} \text { and } 83^{\circ} 54^{\prime} 36^{\prime \prime} \text { longitude } \mathrm{W}\right) \text {, about } 1 \text { year old (Fig. } 1 \mathrm{~d} \text { ), with } 50 \text { individuals/ha and a production of } \\
27.2 \mathrm{Mg} \mathrm{ha}^{-1} \text { year of dry biomass. It was harvested on January of } 2013 \text { and it was sampled only the stem, but leaves and branch were not sampled. } \\
\text { Each plant has only one stem. }\end{array}$ \\
\hline Sorghum bicolor & $\begin{array}{l}\text { It is a rhizomatous plants belonging to the monopodial group (Fig. } 1 \mathrm{e} \text { ). Plantation for experimental purposes and energy production, } 151 \text { days old, in } \\
\text { Upala, Alajuela }\left(10^{\circ} 53^{\prime} 53^{\prime \prime} \text { latitude } \mathrm{N} \text { and } 85^{\circ} 0^{\prime} 57^{\prime \prime} \text { longitude } \mathrm{W}\right) \text {. This crop is planted at } 0.10 \mathrm{~m} \times 0.75 \mathrm{~m} \text {, with a capacity to generate } 26.4 \mathrm{Mg} \text { ha }{ }^{-1} \\
\text { year of dry biomass. It was harvested on February of } 2013 \text { and it was sampled all stem and leaves. Each plant has only one stem. }\end{array}$ \\
\hline
\end{tabular}

\subsubsection{Crop adaptation to the normal wood pellet production process}

The wood pellet manufacturing process at Agrep Forestal S. A. was used (Fig. 2) to make the pellets. The manufacturing process consists of a wood shredder, with loose knife hammers, from which the material is directed towards a pan mill. The ground material passes to a rotary drum dryer $(12 \mathrm{~m}$ long $\times 3 \mathrm{~m}$ ) direct heated by hot air at $400{ }^{\circ} \mathrm{C}$. The particles were then pelletized (KAHL 35-780), with a $780 \mathrm{~mm}$ diameter flat die, orifice channel $30 \mathrm{~mm}$ length and $6 \mathrm{~mm}$ diameter, i.e., the length/diameter is a ratio of 5 . However, three different approaches were used for removing moisture from the crops:

(i) The normal drying stage of the pellet manufacturing process at Agrep Forestal S. A., where the ground material passes to a rotary drum dryer was applied in G. sagittatum and $P$. aurea.

(ii) A stage of pre-air-drying, prior to the normal rotary drum drying stage, was added for $A$. donax and $P$. purpureum. Specifically, the stems with leaves of these species were left in the field (Fig. 3a and b) for a period of three days. This period was selected because it allows the stems begin drying but prevents decay.

(iii) A milling and pressing stages were applicated in S. bicolor in addition to normal rotary drum drying. For milling, a shredding machine, used commonly milling of stem of cane, was used. Afterward a press for water extraction, also common in milling of stem cane, was used.

\subsubsection{Evaluation of moisture loss during the production of pellets from energy crops}

MC was evaluated at each stage of the pellet manufacturing process: (1) harvesting, (2) pre-air-drying (applicated only in A. donax and P. purpureum material) (3) shredding, (4) milling, (5) pressing (applicated in S. bicolor), (6) drying and (7) pellet fabrication. In the harvesting stage, 30 plants per crop were randomly cut and immediately weighed and oven-dried at $103{ }^{\circ} \mathrm{C}$ for $24 \mathrm{~h}$. The dry mass was then determined according to ASTM D-3173 [19].

A pre-air drying stage was added for $A$. donax and P. purpureum. The stem with leaves was left in the field (Fig. 3a and $b$ ) for a period of three days and changes in MC measured. Six samples of 5 plants each were taken for MC measurement. The samples were weighed each day at 10:00 am. After the third day, the samples were dried at $103{ }^{\circ} \mathrm{C}$ for $24 \mathrm{~h}$, weighed and the MC determined. In the remaining stages for these species and others, the MC was determined by removing 10 random samples after each stage and using the ASTM D-3173 procedure.

\subsubsection{Fineness of the particles}

The fineness of particles was measured using different sieves
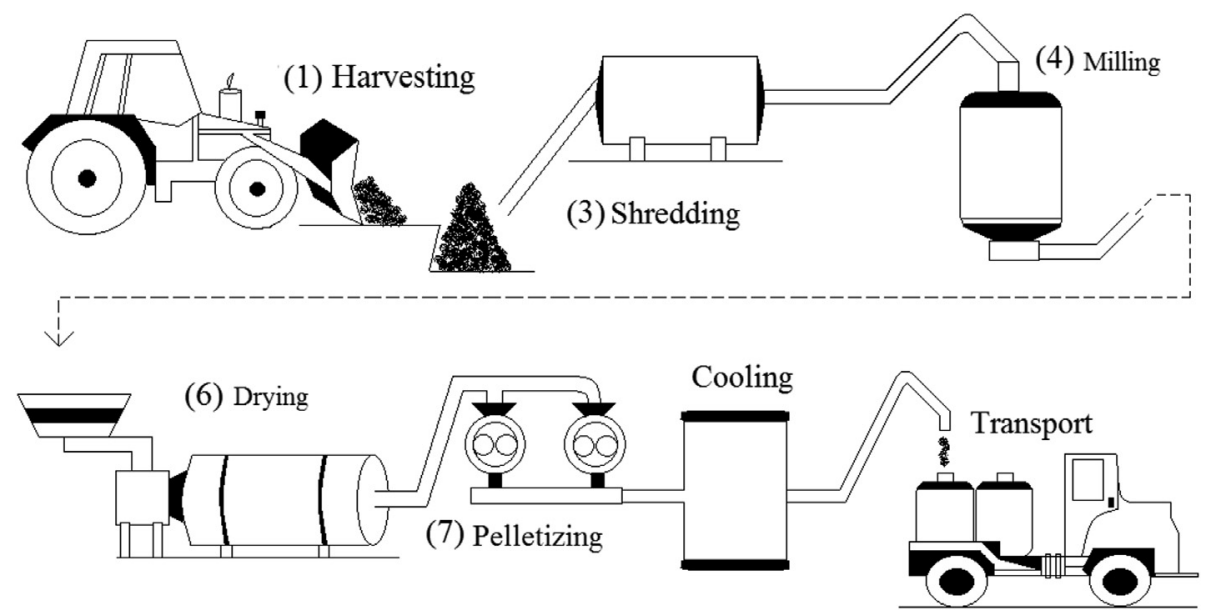

Fig. 2. Wood Pellet manufacturing process in Agrep Forestal S.A. as used in this study. Note: the number in parenthesis represents the stage of process according to Table 3. 

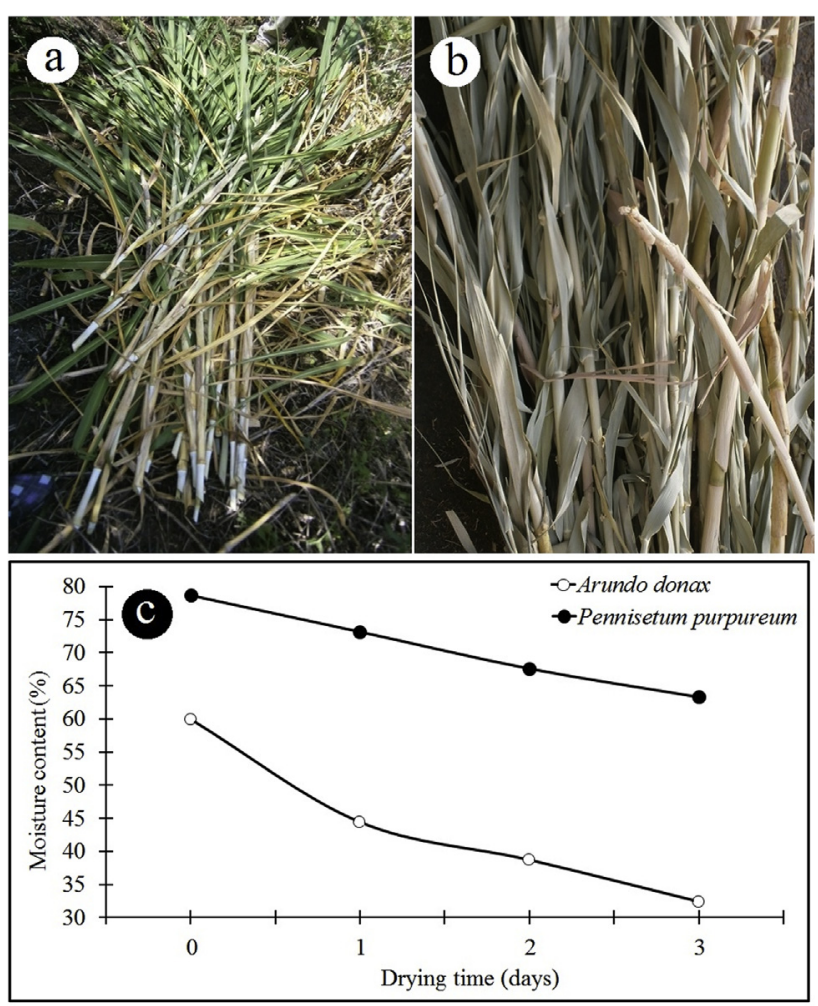

Fig. 3. Stem of Pennisetum purpureum left in the field after harvest (a), Arundo donax air-dried after three day (b) and moisture content reduction in P. purpureum and A. donax in air-drying for three day.

before pelletizing. Ten samples of $100 \mathrm{~g}$, were sieved using a stack of $1 \mathrm{~mm}, 2 \mathrm{~mm}, 4 \mathrm{~mm}, 6.7 \mathrm{~mm}, 8 \mathrm{~mm}, 11.2 \mathrm{~mm}$ and $16 \mathrm{~mm}$ sieves for a period of $2-3 \mathrm{~min}$ and the material in each sieve was then weighed. The particle size distribution was determined by ratio of the mass of the particles retained in each sieve and the total mass of the sample, expressed in percentage. The mass retained in all sieves was named "mass retained" and the mass of particles with size lower than $1 \mathrm{~mm}$ was named "mass not retained". The "mass retained" was then used to calculate the fineness index using (Eq. (1)) as expressed in the Brazilian NBR 7211/83 standard [20].

Fineness index $=\frac{\sum \text { mass retained in sieves }- \text { mass not retained }}{100}$

\subsubsection{Efficiency index of particle-pellet}

The efficiency index of particle-pellet refers to the mass of particles that enter the pelletizing process compared to the amount of pellets with size bigger than $4.75 \mathrm{~mm}$ that are produced. This index was determined by comparing the weight of pellets produced and sieved with a $4.75 \mathrm{~mm}$ (mesh \#4) to the mass of the particle before pelletizing process, expressed in percentage.

\subsection{Quality of the pellets}

Quality of the pellets produced was determined by comparing the ash content, transversal density and longitudinal density. Ash content was unique property evaluated using ASTM 1102-84 after the pellets were 10 randomly selected $2 \mathrm{~g}$ pellet samples were used. Other 10 pellet per crop were selected randomly and conditioned to a moisture content of $12 \%$ prior to evaluation. Pellet quality was then evaluated using X-ray images, which revealed the presence cracks and the area with high density. Variation in quality for longitudinal and transversal density was measured from the images. Cracks are defined as areas where layers in the pellet had separated. The areas with high density are defined when a section of surface area presents density values with values over $1300 \mathrm{~kg} \mathrm{~m}^{-3}$ : X-ray images of the pellet material were taken with X-ray equipment (Hewlett Packard Faxitron, LX-60) using a $12 \mathrm{~cm}$ distance between the X-ray source and the sample. Exposure conditions were $15 \mathrm{~s}$ with $30 \mathrm{kV}$ tube tension. The quantity of cracks is reported as frequency in relation to pellet length (cracks/mm). The images were then analyzed by ImageJ software (National Institute of Mental Health, Bethesda, Maryland, USA) to determine density variation. The digital image in TIFF format is filtered to a threshold equal to 208. Then areas with color higher than 208, were used to represent regions with high density. The frequence (quantity $\mathrm{mm}^{-2}$ ) and percentage of these pellet area with high density was then determined. Likewise, the quality of the pellet was further analyzed using X-ray densitometry to determine the density variation in transverse and longitudinal directions. Pellet density was determined by means of an X-ray scanner (Quintek Measurement Systems Inc, QTRS-01X) and this density was named as "density measured with X-ray". Exposure conditions were of $7 \mathrm{kV}$ in the tube and the density readings were performed for $1 \mathrm{~s}$ each $40 \mu \mathrm{m}$. The first density measurement is named transversal density (TD) and the second one, longitudinal pellet density (LPD). When measuring the transverse and longitudinal density, each pellet was weighed and its diameter and length measured. The samples by crop were fixed in horizontal position on a support and then X-rayed to determine the density in LPD. To determine the TD, the pellets were carefully cut into approximately $1.80 \mathrm{~mm}$ thick sections in the middle of length of pellet which were then X-rayed.

\subsection{Statistical analysis}

An analysis of variance (ANOVA) was used to estimate the differences in GCV, NCV and MC for the stages of the pelletizing process, regarding the fineness index and TD, LPD and their variation coefficient determined by the X-ray densitometry. These variables were established as depend variables and the crop type as independ variable in the ANOVA. The existence of significant differences between the averages for each variable was determined using the Tukey test $(P<0.05)$. Regarding the density values; a correction factor was created for each pellet measured. This factor included the difference between the actual density of each pellet, previously determined by measuring its mass and volume, and average "density measured with X-ray" (Eq. (2)). A factor was determined for both the transversal and longitudinal direction. After each value of density was measured (each $40 \mu \mathrm{m}$ is measured density for X-ray densitometry) it was corrected with the aid of Eq. (3). Then with the corrected density values density profiles in transversal direction (TD) and longitudinal direction (LPD) were constructed to determine patterns of variation of density in both directions.

$$
\begin{aligned}
\text { Correction factor }= & \text { Average density } y_{\text {measured by } x-\text { ray densitometry }} \\
& - \text { Actual density }
\end{aligned}
$$

Corrected density $_{i}=$ Density $_{i}-$ Correction factor

where: Corrected density $y_{i}$ factor per pellets represents density values for each value measured for X-ray densitometry and density $y_{i}$ values measured for X-ray densitometry. Note: density measured 
for X-ray densitometry was read each $40 \mu \mathrm{m}$ in transversal or longitudinal pellet direction.

\section{Results and discussion}

\subsection{Crop characterization}

The caloric values for the raw fibers are shown in Table 2. GCV and vary from 2.5 to $10.3 \mathrm{MJ} \mathrm{kg}^{-1}$, NCV ranges from 17.1 to 20.3 $\mathrm{MJ} \mathrm{kg}^{-1}$; however when calculated for the pellets the variation is smaller, $15.6-17.6 \mathrm{MJ} \mathrm{kg}^{-1}$. Analysis of variance identified three groups in relation to GCV: the first group with the highest values of GCV were: A. donax, G. sagittatum and P. aurea; a second group consisting of $P$. purpureum, which converges with two species of the first group (and converge with G. sagittatum and $P$. aurea), as they contain no statistical differences (Table 2) and a third group, $S$. bicolor, with the lowest GCV. ANOVA applied to NCV distinguished two groups, one composed of $A$. donax, $P$. purpureum and $S$. bicolor with higher values of NCV and a second formed by G. sagittatum and $P$. aurea and two species (A. donax, P. purpureum) that overlap with the first group.

Evaluation of the GCV shows a considerable increase of the caloric value with respect to the NCV (Table 2). This increase is supported by the decrease of the MC in the NCV. For a low MC, higher thermal efficiency is observed in the combustion process, due to lower energy investment in evaporation of water in the biomass [21]. The influence of MC can also be observed in the values of GCV among the different crops; S. bicolor and P. purpureum, with high MC values (Table 3 ) resulting in the lowest values of GCV (2.4 and $7.0 \mathrm{MJ} \mathrm{kg}^{-1}$, respectively). On the other hand, the species A. donax, G. sagittatum and P. aurea, with a MC lower than $60 \%$ (Table 3), resulted in higher GCV values than the previous species (Table 2 ).

NCV and GCV values obtained in pellets from five crops (Table 2) are consistent with the values reported for fast-growing timber species in Costa Rica [22], making them acceptable as an alternative agrifuel. NCV variations between the five crops can be explained by changes in nitrogen and carbon content and the carbon/nitrogen $(\mathrm{C} / \mathrm{N})$ ratio. NCV increased with nitrogen content (Fig. 4a), but decreased with carbon content (Fig. 4b) and $\mathrm{C} / \mathrm{N}$ ratio (Fig. 4c). However, the variation between crops cannot be explained by $\mathrm{C}$ and $\mathrm{N}$ content only as NCV is also affected by other chemical properties. For example, the content and characterization of the ash and the amount of volatile substances positively affect caloric values [23]; however, the extractive content and fixed carbon contribute to an increase in the caloric value [22].

In relation to ash content: the values obtained for ash content ranged from $3.4 \%$ to $10.5 \%$ (Table 2), and all crops presented different ash content, except G. sagittatum and S. bicolor, for which there was no statistical difference. The ash content was higher than those reported for timber species in Costa Rica (between $0.2 \%$ and $4.0 \%$ ) by Moya and Tenorio [10]. Similarly, the ash content values obtained in this study did not comply with the permitted $0.5 \%$ limit according to the DIN 51731 [24] standard or $1.5 \%$ permitted by Swedish standard [25]. Althogh out herbaceous crops are never going to meet the ash content regulations for export, other standards should also be reviewed for the possible qualification of these pellets or these crops could be utilized as complement to other woody energy sources.

\subsection{Crop evaluation in the production process}

\subsubsection{Crop adaptation to the normal wood pellet production process}

Two species (G. sagittatum and P. aurea) among the five crops evaluated, were adapted well to the process used for wood pellet production (harvesting, shredding, milling, drying and pelletizing), whereas for the remaining three ( $A$. donax, $P$. purpureum and $S$. bicolor) required some modifications to the process (Table 3 ). For A. donax the shredding process presented no problems. An airdrying stage to reduce the MC was applied to $A$. donax and P. purpureum (Fig. 3c). The remaining stages for these crops correspond to the normal pelletizing process. In pre-air-drying stage, stems were left in the field for a period of three days after cutting; then the semi-dried material was taken to the shredding process. With S. bicolor it was not necessary to apply the common shredding technique used for woody material; instead, the harvested material was directly milled with an axial-feed mill equipped with four rotating blades. Subsequently, the material received a water extraction pretreatment by compressing it at $8.3 \mathrm{MPa}$ with the press used in the extraction of juice from sugar cane.

G. sagittatum and $P$. aurea adapted well to the existing pelletizing process from Agrep Forestal S. A. Although these crops differ from wood residue in its form (small cylindrical stalks less than $5 \mathrm{~cm}$ diameter), shredding and milling had no problems. The drum type drying system yielded a grinded particle with optimum MC (less than $10 \%$ ) before pelletizing. Another advantage of the system used is that the pellet showed less than $10 \% \mathrm{MC}$ (Table 3). According to McKendry [15], the success of the biomass conversion process into pellets, lies in having a low MC raw material (about 50\%). This research has demonstrated that $G$. sagittatum and $P$. aurea are potential crops for the production of pellets using the same production system used for residue wood. Although S. bicolor, P. purpureum and A. donax are species with high MC (60-80\%), the same machinery to produce pellets from wood residue can be used, although probably affecting the energy balance [25] and representing an increase in costs. High values of MC make it necessary to implement alternative processes (pre-drying or compression of the biomass) to reduce them [25]. This was evidenced by pre-air-drying applied to A. donax and P. purpureum, with which the MC diminished $28 \%$ and $13 \%$, respectively, and a $29 \%$ MC decrease in S. bicolor by applying biomass compression.

Pre-air-drying, as used for A. donax and P. purpureum (Fig. 3a and b), is a practice applied to herbaceous species in some European

Table 2

Calorific values in five agricultural crops studied in Costa Rica.

\begin{tabular}{|c|c|c|c|c|c|}
\hline \multirow[t]{2}{*}{ Agriculture crops } & \multicolumn{2}{|l|}{ Gross calorific } & \multirow[t]{2}{*}{ Net calorific value $\left(\mathrm{MJ} \mathrm{kg}^{-1}\right)$} & \multicolumn{2}{|l|}{ Pellet characteristics } \\
\hline & Value $\left(\mathrm{MJ} \mathrm{kg}^{-1}\right)$ & Moisture content (\%) & & Moisture content (\%) & Ash content (\%) \\
\hline Arundo donax & $10.3^{\mathrm{A}}$ & 60.0 & $19.2^{\mathrm{AB}}$ & 12.0 & $10.5^{\mathrm{A}}$ \\
\hline Gynerium sagittatum & $8.6^{\mathrm{AB}}$ & 57.3 & $17.1^{\mathrm{B}}$ & 9.9 & $4.9^{\mathrm{B}}$ \\
\hline Pennisetum purpureum & $7.0^{\mathrm{B}}$ & 81.0 & $18.5^{\mathrm{AB}}$ & 12.1 & $7.5^{\mathrm{C}}$ \\
\hline Phyllostachys aurea & $7.3^{\mathrm{AB}}$ & 43.4 & $17.9^{\mathrm{B}}$ & 6.7 & $3.4^{\mathrm{D}}$ \\
\hline Sorghum bicolor & $2.4^{\mathrm{C}}$ & 83.5 & $20.3^{\mathrm{A}}$ & 12.6 & $5.5^{\mathrm{B}}$ \\
\hline
\end{tabular}

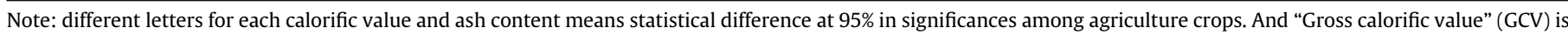
based on the harvest moisture and "Net calorific value" (NCV) is defined based on zero percent in moisture content (MC). 
Table 3

Moisture content of five agricultural cops at different stages of the pellet production process.

\begin{tabular}{|c|c|c|c|c|c|}
\hline Step & Arundo donax & Gynerium sagittatum & Pennisetum purpureum & Phyllostachys aurea & Sorghum bicolor \\
\hline Harvesting & $56.0^{\mathrm{B}}(6.87)$ & $57.3^{\mathrm{B}}(11.50)$ & $81.0^{\mathrm{A}}(2.93)$ & $43.4^{\mathrm{C}}(7.85)$ & $83.5^{\mathrm{A}}(0.51)$ \\
\hline Air-dry & $32.4^{\mathrm{B}}(22.41)$ & - & $68.3^{A}(6.82)$ & - & - \\
\hline Shred & $31.4^{\mathrm{C}}(22.41)$ & $57.0^{\mathrm{B}}(2.50)$ & $67.9^{\mathrm{A}}(1.35)$ & $36.6^{\mathrm{C}}(6.71)$ & - \\
\hline Milled & $25.1^{\mathrm{E}}(6.96)$ & $49.8^{\mathrm{C}}(3.30)$ & $64.1^{\mathrm{B}}(1.18)$ & $34.9^{\mathrm{D}}(3.81)$ & $81.9^{\mathrm{A}}(0.51)$ \\
\hline Pressed & - & - & - & - & $52.4(2.64)$ \\
\hline Dry & $12.5^{\mathrm{B}}(3.28)$ & $9.7^{C}(6.17)$ & $15.0^{\mathrm{A}}(2.22)$ & $7.6^{\mathrm{D}}(3.20)$ & $14.6^{\mathrm{A}}(10.74)$ \\
\hline Pelletized & $12.0^{\mathrm{B}}(4.70)$ & $9.8^{\mathrm{C}}(2.14)$ & $12.1^{\mathrm{AB}}(3.80)$ & $6.7^{\mathrm{D}}(5.85)$ & $12.6^{\mathrm{A}}(5.56)$ \\
\hline
\end{tabular}

Note: Superscript letters indicate statistical differences at 95\% in significances among agriculture crops between moisture contents and same step.
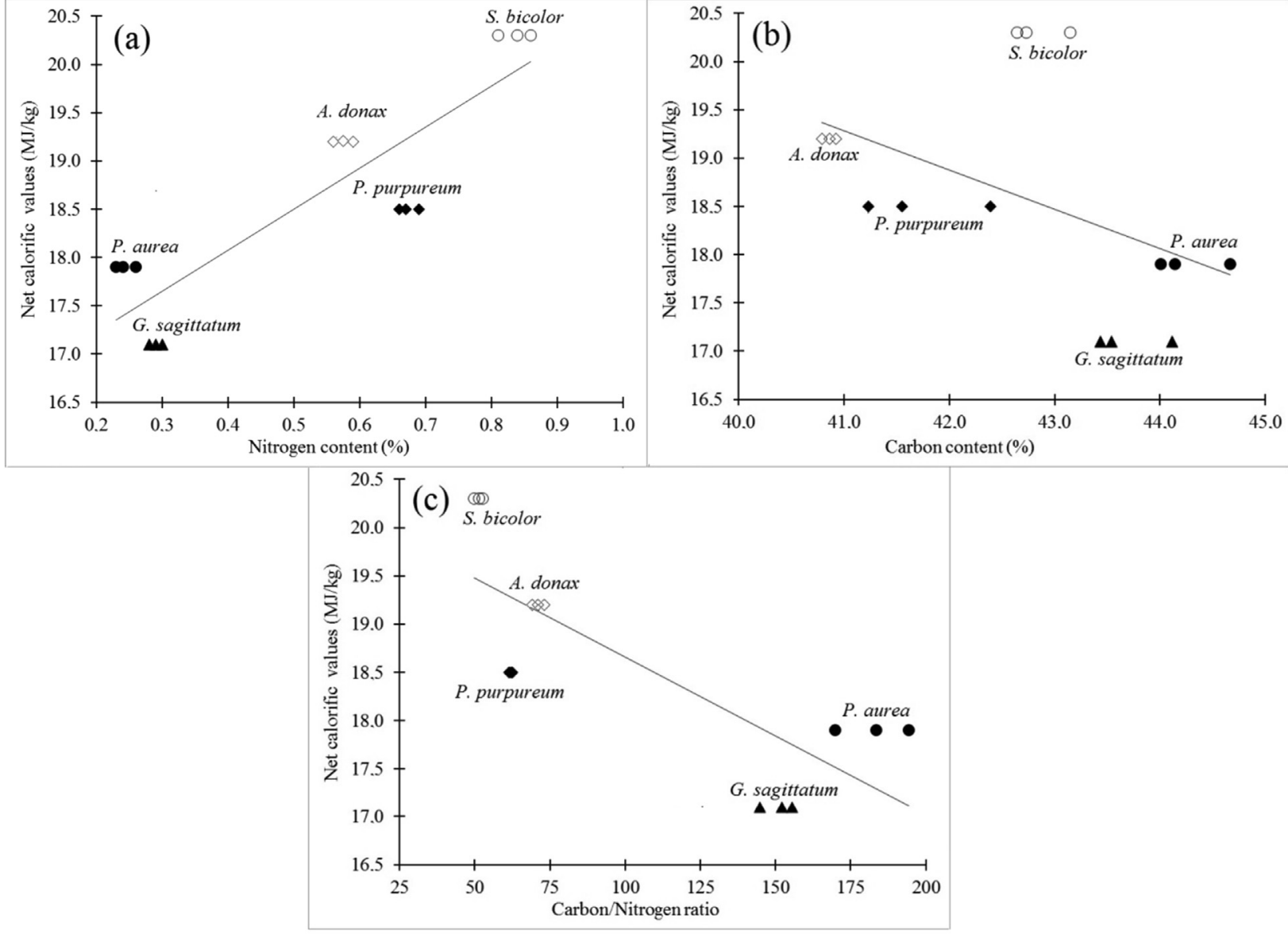

Fig. 4. Relationships between carbon (a), nitrogen (b) and carbon/nitrogen ratio (c) with net caloric values for pellets manufactured with five energy crops.

countries to maintain the energy balance [26]. However, for tropical countries this should be handled more carefully, as these regions have two seasons, dry and wet. The rainy season prevails for most of the year, characterized by the presence of high relative humidity, which causes the biomass MC reduction to be slow [10], while promoting the biological degradation of the biomass.

Regarding biomass compression, as applied to $S$. bicolor, specialized equipment for the extraction of sugar cane juice was used. The result was successful as demonstrated in the decrease in MC from 81.9 to $52.4 \%$ (Table 3). Unlike timber, which is composed of highly bonded fibers and a hard outer surface, moisture removal in the crops studied by mechanical means is possible, since they are herbaceous plants that have more flexible bonded fibers [15], which enable the compression of the biomass to extract the water trapped in the tissues.

\subsubsection{Fineness of the particles}

The evaluation of fineness of the particles before pelletizing showed that the crops can be divided into four groups (Fig. 5a): the first, with the highest fineness index (0.34), comprising $P$. aurea; the second, with indexes between 0.27 and 0.29 , including G. sagittatum and P. purpureum, a third group integrated by $S$. bicolor and $A$. donax with the lowest fineness index. These differences arose from the variation in particle size for each crop. A high percentage of large particles $(4-16 \mathrm{~mm})$ decreased the fineness index value, as in $S$. bicolor and $A$. donax, which have the highest percentages (Table 4). Contrary, a high percentage of particles with size less than $4 \mathrm{~mm}$, as in the case of $G$. sagittatum, $P$. purpureum and $P$. aurea, produced the lowest fineness index values (Fig. 5a). The variation in particle size was influenced by two factors: (i) not applying the same manufacturing process for the 5 species, such as 

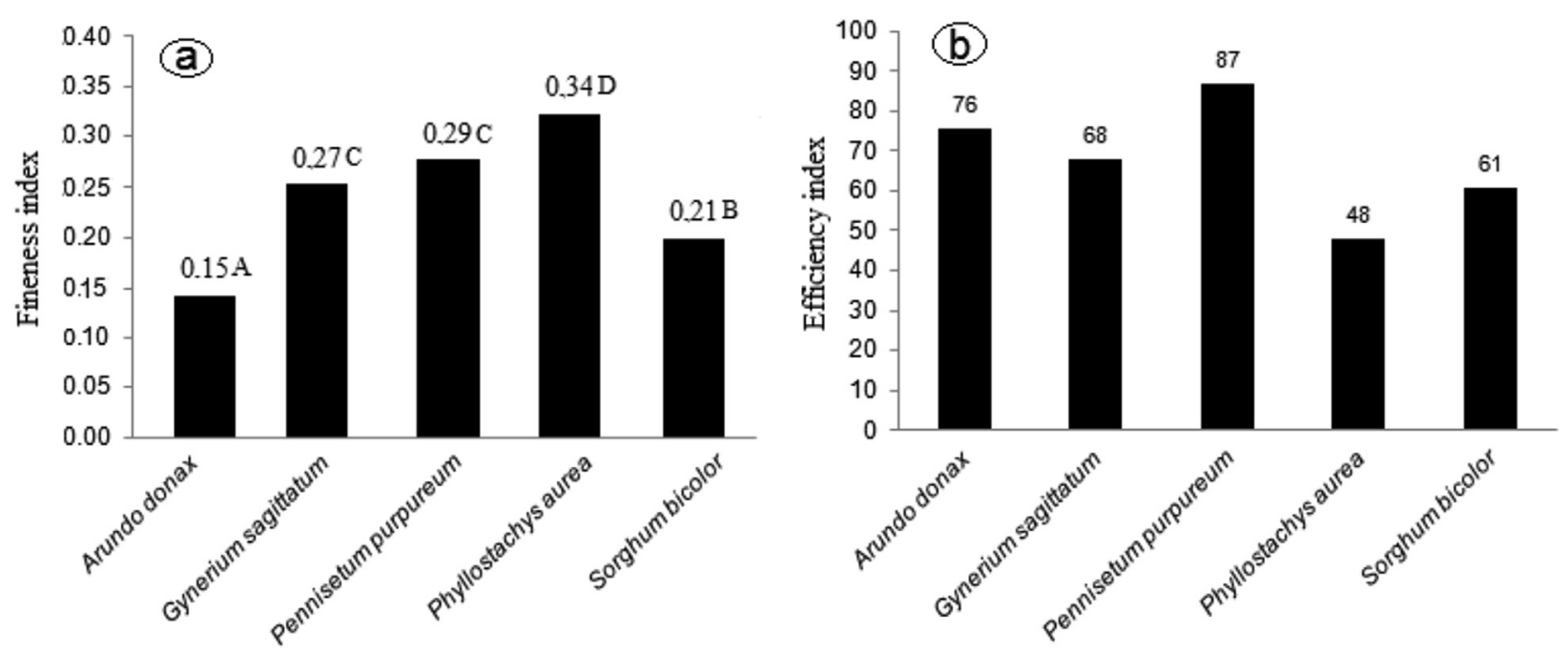

Fig. 5. Values obtained for five energy crops in (a) fineness index and (b) efficiency index. Note: different letters for each value means statistical significances at $95 \%$.

Table 4

Particle size distribution (percentage) in relation to weight before pelletizing for five agricultural crops studied in Costa Rica.

\begin{tabular}{|c|c|c|c|c|c|}
\hline Particle size in length $(\mathrm{mm})$ & Arundo donax & Gynerium sagittatum & Pennisetum purpureum & Phyllostachys aurea & Sorghum bicolor \\
\hline$>16.00$ & 0.33 & 0.68 & 1.57 & 0.00 & 10.29 \\
\hline $16.00-11.20$ & 0.98 & 0.09 & 3.08 & 0.09 & 2.24 \\
\hline $11.20-8.00$ & 5.12 & 1.81 & 3.28 & 0.88 & 3.71 \\
\hline $8.00-6.70$ & 3.49 & 3.10 & 1.46 & 0.93 & 2.38 \\
\hline $6.70-4.00$ & 34.28 & 21.17 & 22.62 & 12.40 & 18.34 \\
\hline $4.00-2.00$ & 24.81 & 33.49 & 21.90 & 32.93 & 26.12 \\
\hline $2.00-1.00$ & 15.17 & 12.82 & 16.75 & 18.51 & 15.85 \\
\hline$<1.00$ & 15.81 & 26.83 & 29.34 & 34.26 & 21.06 \\
\hline
\end{tabular}

reducing the size of the biomass in $A$. donax (shredding) and $S$. bicolor (milling), as well as the MC reduction, where the shape and size of the particles was dependant on the milling parameters (hammers, blades and rotation speed) [27] and (ii) characteristics of the raw material. Species with less lignified tissues tend to bend, and thus to shred into long pieces, while species with more lignified tissues tend to break rather than bend, and thus are fragmented into shorter chunks [28].

\subsubsection{Evaluation of moisture loss during the production of pellets} from energy crops

P. purpureum and S. bicolor had the highest average MC (81 and 85.5) during the harvest season, while A. donax, G. sagittatum and $P$. aurea had the lowest (56, 57.3 and 43.4 respectively) (Table 3 ). For the two species that used an air-drying stage it was determined that $A$. donax has a lower MC at this stage than P. purpureum. In the grinding stage, the MC values were statistically different for the 5 crops, ranging from 81.9 to $25.1 \%$ for $S$. bicolor and A. donax respectively. The MC after drying and after the biomass had been pelletized, was statistically different for the 5 crops, ranging from 7.6 to $15.0 \%$ after drying and $6.7-12.6 \%$ after pelletizing. $P$. purpureum and S. bicolor presented the highest values in both stages, followed by A. donax, G. sagittatum and $P$. aurea, which showed the lowest values (Table 3 ).

The pre-air-drying of stems of $A$. donax and $P$. purpureum resulted in a $27 \%$ and $13 \%$ reduction in MC over the three days (Fig. 3c). In the shredding stage of the applied crops, the MC decreased only $1-2 \%$ (Table 3 ), with the exception of $P$. aurea. In the case of biomass milling, the MC reduction in relation to the previous stage increased from 2 to $7 \%$, the lower value being for $P$. aurea and the highest value for G. sagittatum. In S. bicolor, where pressing before drying was applied, a 29.5\% MC reduction was observed. As expected, drying resulted in the largest reduction of MC for all processes. Finally, in the pelletizing process, the MC diminished in the 5 crops and varied from approximately $1-3 \%$.

\subsubsection{Efficiency index of particle-pellet}

The highest efficiency index was obtained for $P$. purpureum, followed by A. donax, G. sagittatum and S. bicolor with values of 68 and $61 \%$, respectively. P. aurea presented the lowest index (Fig. 5b). The variation in the efficiency index for the five crops (Fig. 5b), is dependant on a number of factors that affect the compression of the biomass. In herbaceous plants, lignin and proteins are responsible for making connections between particles, and the index of these compounds varies according to the type of biomass [29]. Also, the $\mathrm{MC}$ of the biomass before pelleting is one of the major factors [30]. This study showed that when the MC ranged from 10 to $15 \%$, as in P. purpureum, A. donax and G. sagittatum, it resulted in a higher efficiency index, whereas when the MC of the particles before pelleting was less than $10 \%$ ( $P$. aurea), the lowest efficiency index was obtained. Excessive drying, as occurred in $P$. aurea, has a hardening effect on the tissue surface and serves as a thermal insulator, thus preventing heat transfer, which is a key element for compression [29]. The low yield of S. bicolor in relation to A. donax and $P$. purpureum, cannot be explained by the $\mathrm{MC}$, since this crop is within the optimum range of MC (Table 3 ) but may be explained by the high content of large particles ( $16 \mathrm{~mm})$, having been found that fine particles (2 $\mathrm{mm})$ improve binding [31].

\subsection{Pellet quality}

The presence of cracks is one aspect of pellet quality, since they 
are directly related to the susceptibility of breakage [32]. The evaluation using X-ray images shows that surface cracks were the lowest in the pellets manufactured with P. purpureum (Table 5) and this crop presented only some irregularities (Fig. 6e). For S. bicolor and $A$. donax the quantity of cracks was higher than $P$. purpureum (Table 5, Fig. 6a and c). The highest quantity was observed in pellets manufactured with P. aurea and G. sagittatum (Table 5, Fig. 6d and b), being most evident in $P$. aurea.

X-ray images showed that cracks were present in varying degrees for all crops (Table 5, Fig. 6). The presence of these cracks is common in milled materials once pelletized [33] and is attributed to inadequate MC for pelletizing or to inadequate particle size. MC significantly affects the physical properties of densifying the biomass [34], since the presence of water strengthens the bonds between particles. The decrease in water reduces the capillary force that maintains the structure of the pellet, leaving cracks. This is seen in the results, where those crops that presented MC between 12 and 15\% (A. donax, P. purpureum, and S. bicolor) showed fewer cracks, whereas $P$. aurea and $G$. sagittatum, species with MC values of $7 \%$ and $10 \%$, respectively, showed a higher number of cracks in the pellet surface.

The presence of cracks also shows that there is an inadequate efficiency pelletization of biomass. The presence of cracks is negatively related to the efficiency index (Fig. 7a), indicating a low value of this index. Then low conversion efficiency of particulate to pellet consequently increase in the probability that the pellet to break and therefore less durability [33], because of the relationship of durability and cracks presence.

Another aspect made evident by the X-ray images, is the presence of light colored areas in the pellet, which is more frequent, therefore high in relation to total area (Table 5), in A. donax (Fig. 6a), followed by P. purpureum, G. sagittatum (Fig. 6b andc) and lastly, by $P$. aurea and S. bicolor where such areas are minor frequency and less area in relation to total area (Table 5, Fig. 6d-e). Light areas observed in pellets are related to variations in density (Fig. 8b-e). These regions correspond to differences in size and structure of the pelletized particles, due to the heterogeneous anatomical structure of the crops. For example, the P. purpureum has a higher concentration of fibers in the outer layers of the stem, and cutinized and waxy layers [35], which results in density increasing from the inner part to the outer part [36]. Another example is the species A. donax whose anatomical structure varies between the nodes and internodes and with increased wall thickness of the fiber at the nodes [37]. This variation of the structure and the presence of regions of high density in the plant, causes these parts to remain located at certain regions of the pellet during milling, resulting in an increase in density in that region (Fig. 8b-e).

\subsection{Pellet density}

The pellet density values, for both TD and LPD, for the five crops ranged from 1129 to $1293 \mathrm{~kg} \mathrm{~m}^{-3}$ and three different groups were

Table 5

Parameters characteristics of light zones in surface pellet in five agricultural crops in Costa Rica.

\begin{tabular}{llll}
\hline Agricultural crops & Cracks $/ \mathrm{mm}$ & Light areas $/ \mathrm{mm}^{2}$ & Area of light (\%) \\
\hline Arundo donax & $3.0^{\mathrm{B}}$ & $12.97^{\mathrm{A}}$ & $3.43^{\mathrm{A}}$ \\
Gynerium sagittatum & $5.5^{\mathrm{A}}$ & $2.77^{\mathrm{C}}$ & $1.34^{\mathrm{B}}$ \\
Pennisetum purpureum & $0.9^{\mathrm{C}}$ & $5.28^{\mathrm{B}}$ & $1.46^{\mathrm{B}}$ \\
Phyllostachys aurea & $6.1^{\mathrm{A}}$ & $1.43^{\mathrm{D}}$ & $1.03^{\mathrm{C}}$ \\
Sorghum bicolor & $2.5^{\mathrm{B}}$ & $1.30^{\mathrm{D}}$ & $0.27^{\mathrm{D}}$ \\
\hline
\end{tabular}

Note: different letters for each parameter means statistical differences significant at 95\% among agriculture crops.
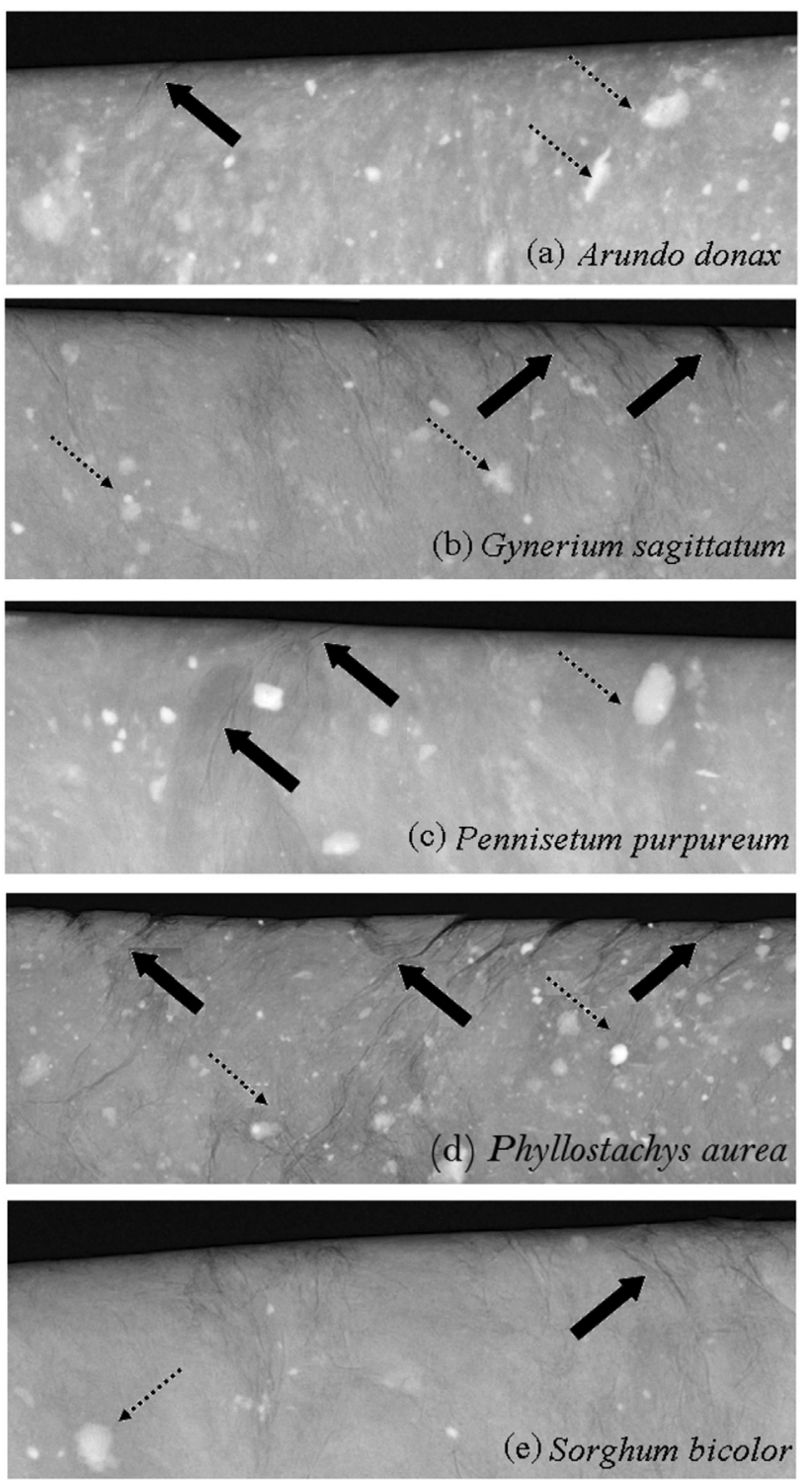

Fig. 6. X-ray photograph of the surface of the pellets manufactured with five energy crops. Note: The mark $\Rightarrow$ indicates the presence of cracks in the surface and the mark $\rightarrow$ indicates a light colored area.

established (Table 6): the first group consisting of high density species, $A$. donax and $P$. purpureum, with no statistical differences between the values of density; a second intermediate density group, including G. sagittatum and P. aurea; and a third group, also composed of $P$. aurea and $S$. bicolor (together $P$. aurea), forming pellets of lower density. There was trendency of diminished density with the decrease in the MC of the pellet. P. purpureum and A. donax had the highest density values, with $12.11 \%$ and $11.98 \%$ MC respectively, then $G$. sagittatum with $9.85 \% \mathrm{MC}$ and $P$. aurea with $6.68 \%$ MC. These last two species showed a large quantity of cracks (Table 5), which are empty spaces with resulting density reduction. However, S. bicolor obtained the lowest density value (Table 6) with $12.64 \%$ MC, which demonstrates that, similarly, with an increase of the pellet MC to over $12 \%$, the density tends to diminish [31]. In addition, a ratio of the density of the species to the fineness index was established, since the coarse grain size makes the arrangement of large particles difficult compared to small particles [38].

The TD variation of the pellet was greater than LPD (Table 6). 


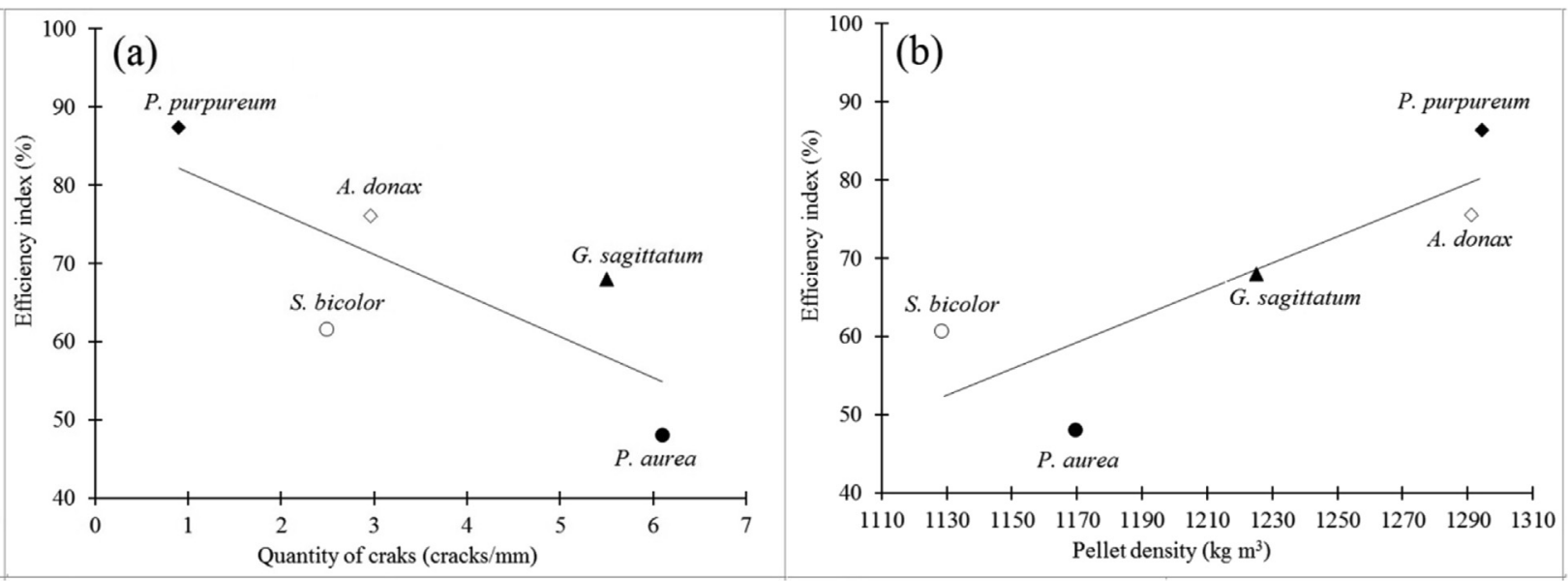

Fig. 7. Relationships between efficiency index with quantity of crack (a) and density (b) for pellets manufactured with five energy crops.
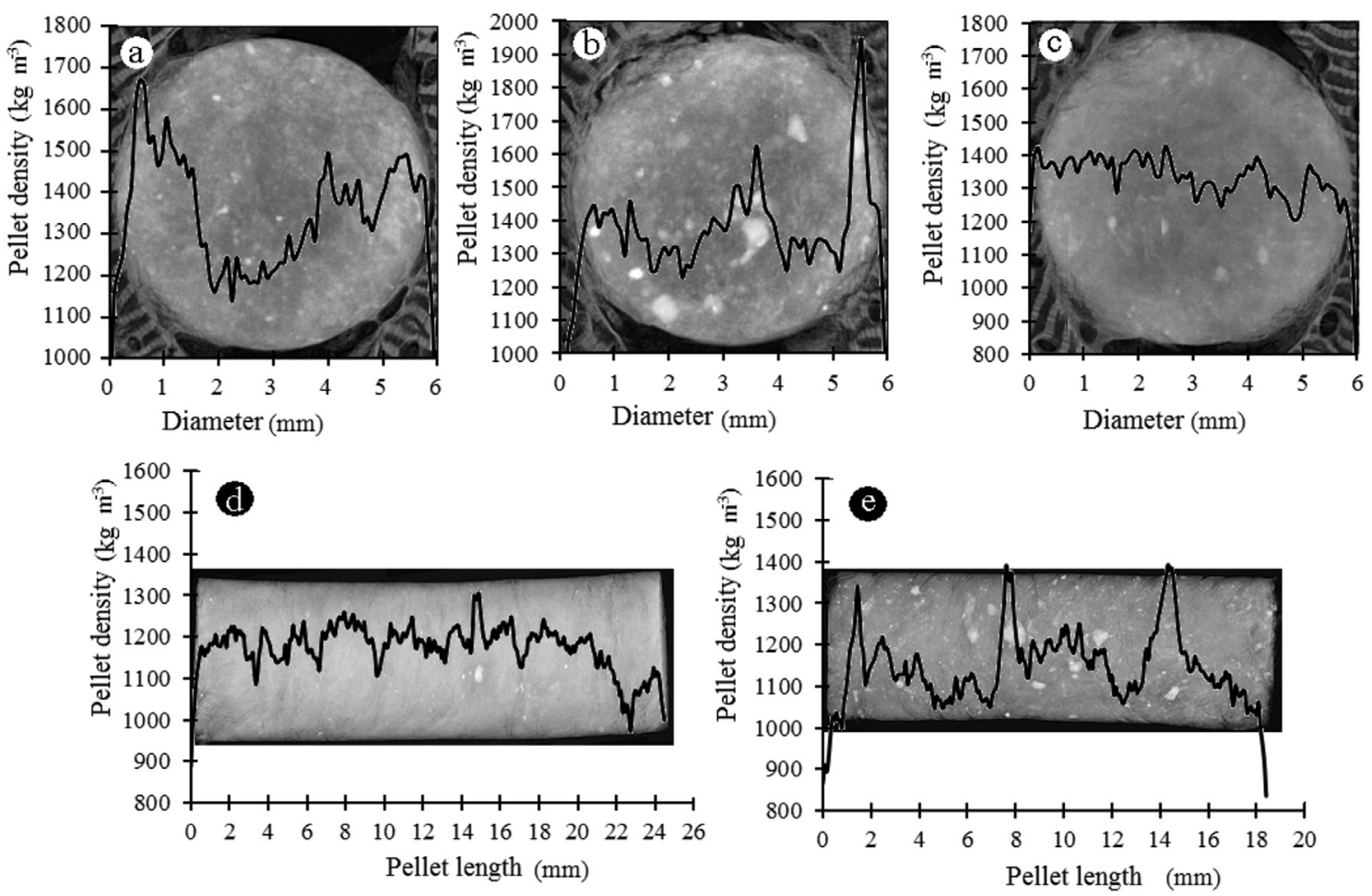

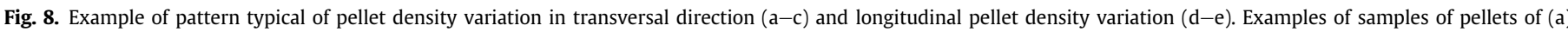
Arundo donax (b) Arundo donax (c) Pennisetum purpureum (d) Sorghum bicolor (e) Phyllostachys aurea.

Table 6

Longitudinal and transversal pellet density obtained by X-ray densitometry in transversal and length direction in five agricultural crops in Costa Rica.

\begin{tabular}{|c|c|c|c|c|}
\hline \multirow[t]{2}{*}{ Agricultural crops } & \multicolumn{2}{|c|}{ Longitudinal pellet density } & \multicolumn{2}{|l|}{ Transversal density } \\
\hline & Average $\left(\mathrm{kg} \mathrm{m}^{-3}\right)$ & Coefficient of variation (\%) & Average $\left(\mathrm{kg} \mathrm{m}^{-3}\right)$ & Coefficient of variation (\%) \\
\hline Arundo donax & $1291.9^{\mathrm{A}}$ & $9.7^{\mathrm{A}}$ & $1292.0^{\mathrm{A}}$ & $15.3^{\mathrm{A}}$ \\
\hline Gynerium sagittatum & $1225.1^{\mathrm{B}}$ & $6.3^{\mathrm{AB}}$ & $1225.1^{\mathrm{B}}$ & $10.4^{\mathrm{B}}$ \\
\hline Pennisetum purpureum & $1293.9^{\mathrm{A}}$ & $6.2^{\mathrm{AB}}$ & $1293.9^{\mathrm{A}}$ & $16.1^{\mathrm{A}}$ \\
\hline Phyllostachys aurea & $1169.6^{\mathrm{BC}}$ & $7.4^{\mathrm{AB}}$ & $1169.6^{\mathrm{BC}}$ & $9.9^{\mathrm{B}}$ \\
\hline Sorghum bicolor & $1129.1^{\mathrm{C}}$ & $5.3^{\mathrm{B}}$ & $1129.1^{\mathrm{C}}$ & $13.4^{\mathrm{AB}}$ \\
\hline
\end{tabular}

Note: different letters for each parameter means statistical differences, significant at 95\% among agriculture crops.

This difference is a result of the three density profiles found in the $\mathrm{TD}$, the irregular profile is the one that is present in greater amounts in the pellets analyzed for each crop. This confirms that the process of pellet manufacturing generates heterogeneous 
particle sizes, which favors a heterogeneous densification [38]. High density values around the surface of the pellet in relation to the central part were also observed (Fig. 8a-c). This pattern was present in a study of transversal density variation with wood briquettes of Eucalyptus species, where the external high density of the briquette is explained by the variation in temperature and internal pressure of the briquette [38].

The evaluation of the TD of the pellet shows three patterns of variation: high density around the surface, uneven density and uniform density. The first pattern has a greater density variation on the longitudinal orientation of the pellet and a lower density in the interior (Fig. 8a); the pattern of irregular density shows high values of density at any point in the pellet diameter (Fig. 8b), and the uniform density pattern presents similar values along the diameter (Fig. 7c). Examples of the first pattern are A. donax and P. purpureum (Fig. 8a and c). The second pattern (Fig. 8b) is evident in A. donax, $P$. purpureum and $P$. aurea. Lastly, the uniform density pattern
(Fig. 8c) can be clearly observed in all five crops.

Meanwhile, two density variation patterns were determined in LPD: uniform density and irregular density. For the first pattern, there is little variation (Fig. 8d). There is irregularity in the density of the pellet in the second pattern, with areas of low or high density (Fig. 8e). Fig. 9 shows examples of the variation of LPD for the 5 species. This figure also shows that the uniform density variation pattern was found for S. bicolor (Fig. 9a), and this uniformity begins to diminish in P. purpureum and G. sagittatum (Fig. 9b-c) until reaching the irregular pattern for P. aurea and A. donax (Fig. 9d-e).

The pellet density and the presences of cracks (Fig. 7a) were related to the efficiency index. The relationship between the density and the efficiency index for the five crops was positively correlated (Fig. 7b), indicating that a pellet with high density is one with high conversion efficiency.

The analysis of density variation by means of the coefficient of variation (CV) showed a lower density value in LPD than in TD

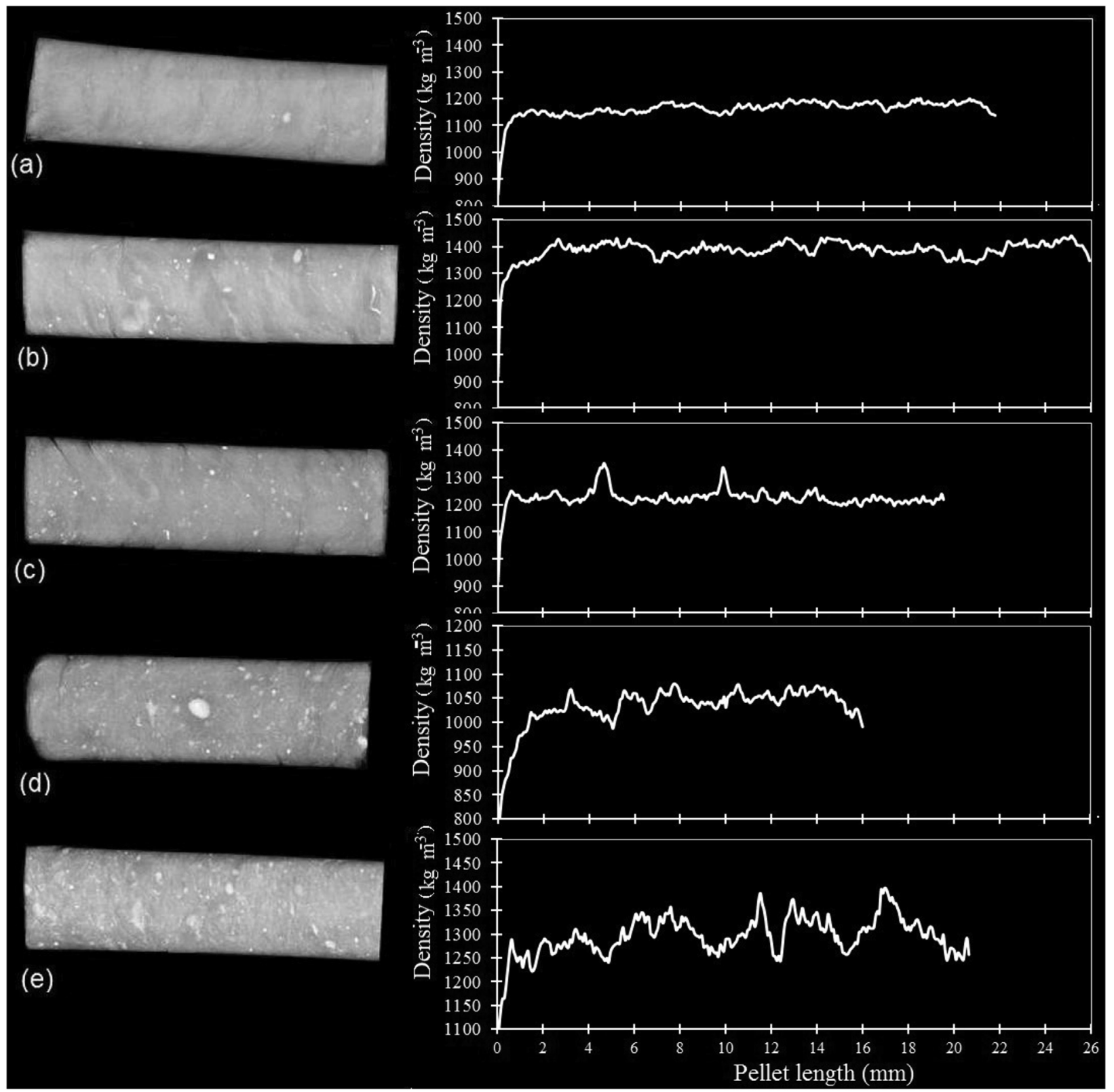

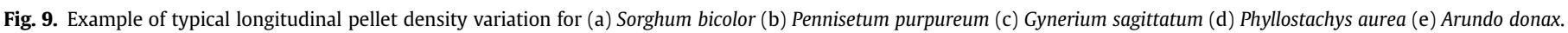


(Table 6). ANOVA determined that $A$. donax was the species with the highest CV, whereas the lowest was S. bicolor. However, both crops have no statistical differences between the other species. Differences of the CV in the TD can be used to divide the crops in two groups: the first with statistically higher values: $P$. purpureum and A. donax, and the second group composed of $G$. sagittatum and P. aurea. S. bicolor shows no statistical difference with respect to either group.

Examples of density profiles for LPD (Fig. 9) show the varying CV found for the five species (Table 5). The irregularity of density throughout the pellet and the presence of sharp peaks in $P$. aurea and A. donax (Fig. 9d and e) are consistent with the highest CV values (Table 6). Also in these species, the high variability in density may also be related to the large abundance of clear zones or areas of higher density (Fig. 6a and d). By contrast, a uniform density profile (Fig. 9a) as for S. bicolor, show low CV (Table 6) and few zones of high density or light areas (Fig. 8e).

The evaluation of pellet quality using both cracks presence and density profile, indicates the degree of efficiency of the pelletizing process [30], where efficiency is related to the amount of compressed material and the pressure generated. This measurement technique can be used to explain the subsequent performance in pellet quality as the presence of cracks and high variability of density have been shown to effect pellet durability and fragility [29]. Considering this and other results, the pelleting process applied to $P$. aurea produces a lower quality pellet in relation to the species P. purpureum, A. donax, G. sagittatum and S. bicolor, due to their high amount of cracks and lower density. However, G. sagittatum also contained high quantities of cracks and S. bicolor had the lowest density value.

\section{Conclusions}

- This work demonstrated that G. sagittatum and Phyllostachys aurea can be used to successfully produce pellets using the process used by Agrep Forestal S. A. (harvesting, shredding, milling, drying and pelletizing) and that S. bicolor, P. purpureum and $A$. donax, species with high MC, required air drying stage to reduce the MC (approximately 13-29\%).

- The net caloric value for the pellets from these five crops varied from 15.6 to $17.6 \mathrm{MJ} \mathrm{kg}^{-1}$ with ash content variation from $3.4 \%$ to $10.5 \%$. The initial moisture content was over $57 \%$ almost species except $P$. aurea (with 43\%). The ash content was high (from $3.4 \%$ to $10.5 \%$ ), which will not meet the ash content regulations as DIN or Swedish standard; however it necessary to reviewed for the possible qualification of these from these crops for utilizing as complent to other woody energy source.

- The adaption of this pelletizing process for the five crops generated two major differences: a variation in the distribution of particle size, with the consequent change in the fineness index; and the efficiency index of particle-pellet was different in each crop which is negatively related with crack presence.

- As to the quality of the pellet, it was found that in P. purpureum, A. donax and S. bicolor, the moisture content varied from 11 to $13 \%$, whereas in G. sagittatum and P. aurea, the moisture content was less than $10 \%$. Cracks were present in varying degrees for all crops, with the largest quantity of surface cracks observed in pellets manufactured with $P$. aurea and $G$. sagittatum, and with S. bicolor, A. donax and P. purpureum having the smallest quantity. The pellet density values, for both TD and LPD, for the five crops ranged from 1129 to $1293 \mathrm{~kg}$, however transversal variation was greater than longitudinal variation. A. donax was the species with the highest $\mathrm{CV}$, whereas the lowest was for S. bicolor.
- Finally, the results indicate that $P$. aurea produces a lower quality of the pellet in relation to the species P. purpureum, A. donax, G. sagittatum and $S$. bicolor, due to the large amount of cracks and low density of $P$. aurea. However, G. sagittatum also contained large quantities of cracks and S. bicolor had the lowest density value, resulting in lower quality pellets.

\section{Acknowledgment}

The authors wish to thank the Vicerrectoría de Investigación y Extensión at the Instituto Tecnológico de Costa Rica (ITCR), Ingenio Taboga and Ingenio el Viejo, with special thanks to Dr. Fermin Subiros for the raw materials and facilities for the study.

\section{References}

[1] J.B. Ulloa, J.H. Weerd, E.A. Huisman, J.A. Verreth, Tropical agricultural residues and their potential uses in fish feeds: the Costa Rica situation, Waste Manag. 24 (1) (2004) 87-97.

[2] F. Ramírez, E. Carazo, C. Roldán, G. Villegas, Encuesta de oferta y consumo energético nacional a partir de la biomasa en Costa Rica año 2006, San José Costa Rica, 2007.

[3] R. Serrano, R. Moya, Procesamiento, uso y mercado de la madera en Costa Rica: aspectos históricos y análisis crítico, Rev. For. Mesoam. Kurú 8 (21) (2011) 1-12.

[4] J. Espinoza, R. Moya, Aprovechamiento e industrialización de dos plantaciones de Gmelina arborea de 15 años en diferentes condiciones de pendiente, Rev. Chapingo Ser. Cie. 19 (2) (2011) 238-248.

[5] L.R. Chacón, Diagnóstico de las existencias de los residuos forestales en la región Huetar Norte de Costa Rica, San José, 2012.

[6] W. Stelte, J. Holm, A. Sanadi, S. Barsberg, J. Ahrenfeldt, U. Henriksen, Fuel pellets from biomass: the importance of the pelletizing pressure and its dependency on the processing conditions, Fuel 90 (11) (2011) 3285-3290.

[7] V. Karkania, E. Fanara, A. Zabaniotou, Review of sustainable biomass pellets production - a study for agricultural residues pellets' market in Greece, Renew. Sust. Energy Rev. 16 (3) (2012) 1426-1436.

[8] S. Mani, S. Sokhansanj, A. Turhollow, Economics of producing fuel pellets from biomass, Appl. Eng. Agric. 22 (3) (2006) 421-426.

[9] A. Barrantes, S. Ugalde, Usos y aportes de la madera en Costa Rica: Estadísticas 2011, San José, Costa Rica, 2012.

[10] C. Tenorio, R. Moya, Evaluation of different approaches for the drying of lignocellulose residues, Bioresources 7 (3) (2012) 3500-3514.

[11] A. Ruiz, F. Cuadros, F. López, Characterization of pellets from industrial tomato residues, Food Bioprod. Process. 90 (4) (2012) 700-706.

[12] R. Moya, D. Camacho, J. Mata, R. Soto, Fungal decay, coating, burning properties and change of color of particleboards manufactured with woody biomass, agricultural wastes and tetra pak residues, J. Biomater. Nanobiotechnol. 4 (4) (2013) 334-342.

[13] L. Carvalho, E. Wopienka, C. Pointner, J. Lundgren, V. Kumar, W. Haslinger Performance of a pellet boiler fired with agricultural fuels, Appl. Energy 104 (2013) 286-296.

[14] P. McKendry, Energy production from biomass (part 2): conversion technologies, Bioresour. Technol. 83 (1) (2002) 47-54.

[15] P. McKendry, Energy production from biomass (part 1): overview of biomass, Bioresour. Technol. 83 (1) (2002) 37-46.

[16] A. Dunnett, C. Adjiman, N. Shah, Biomass to heat supply chains: applications of process optimization, Process Saf. Environ. 85 (5) (2007) 419-429.

[17] C.N. Hamelinck, R.A. Suurs, A.P. Faaij, International bioenergy transport costs and energy balance, Biomass Bioenergy 29 (2) (2005) 114-134.

[18] ASTM, Standard Test Method for Gross Calorific Value of Coal and Coke, D 5865-04, American Society for Testing and Materials, Philadelphia (PA), 2003.

[19] ASTM, Standard Test Method for Moisture in the Analysis Sample of Coal and Coke, D 3173-11, American Society for Testing and Materials, Philadelphia (PA), 2003.

[20] NBR. Agregado para Concreto, NBR 7211/83. Rio de Janeiro; Associação Brasileira de Normas Técnicas: 1983.

[21] Z. Liu, A. Quek, R. Balasubramanian, Preparation and characterization of fuel pellets from woody biomass, agro-residues and their corresponding hydrochars, Appl. Energy 113 (2013) 1315-1322.

[22] R. Moya, C. Tenorio, Características de combustibilidad de diez especies de plantaciones de rápido crecimiento en Costa Rica, Rev. For. Mesoam. Kurú 10 (24) (2013) 2215-2504.

[23] J. Gominho, A. Lourenco, I. Miranda, H. Pereira, Chemical and fuel properties of stumps biomass from Eucalyptus globulus plantations, Ind. Crop. Prod. 39 (2012) 12-16.

[24] DIN 51731, Testing of Solid Fuels - Compressed Untreated Wood - Requirements and Testing, Deutsches Institut für Normung, Berlin, 1996; a R. Moya, C. Tenorio, B. Bond, Energy balance for three lignocellulosic residues using different drying techniques, Bioresources 8 (2) (2013) 2033-2046.

[25] SS, SS 187120: Biofuels and Peat, Fuel Pellets. Classification, Swedish 
Standards Institution; Swish, Stockholm, Sweden, 1998;

a L. Angelini, L. Ceccarini, E. Bonari, Biomass yield and energy balance of giant reed (Arundo donax L.) cropped in central Italy as related to different management practices, Eur. J. Agron. 22 (4) (2005) 375-389.

[26] P. Daugbjerg, M. Temmerman, S. Westborg, Internal particle size distribution of biofuel pellets, Fuel 90 (3) (2011) 980-986.

[27] M. Da Silva, D. Santos, L. Nunes, G. Gustinelli, F. de Oliveira, F. Krug, Evaluation of grinding methods for pellets preparation aiming at the analysis of plant materials by laser induced breakdown spectrometry, Talanta 85 (4) (2011) $1744-1750$.

[28] C. Serrano, E. Monedero, M. Lapuerta, H. Portero, Effect of moisture content, particle size and pine addition on quality parameters of barley straw pellets, Fuel Process. Technol. 92 (3) (2011) 699-706.

[29] I. Relova, S. Vignote, M.A. León, Y. Ambrosio, Optimisation of the manufacturing variables of sawdust pellets from the bark of Pinus caribaea Morelet: particle size, moisture and pressure, Biomass Bioenergy 33 (10) (2009) 1351-1357.

[30] S. Mani, L. Tabil, S. Sokhansanja, Effects of compressive force, particle size and moisture content on mechanical properties of biomass pellets from grasses, Biomass Bioenergy 30 (7) (2006) 648-654.
[31] W. Stelte, J. Holm, A. Sanadi, S. Barsberg, J. Ahrenfeldt, U. Henriksen, A study of bonding and failure mechanisms in fuel pellets from different biomass resources, Biomass Bioenergy 35 (2) (2011) 910-918.

[32] N. Kaliyan, V. Morey, Factors affecting strength and durability of densified biomass products, Biomass Bioenergy 33 (3) (2009) 337-359.

[33] O. Fasina, Physical properties of peanut hull pellets, Bioresour. Technol. 99 (2008) 1259-1266.

[34] M. Pereira, A. Beraldo, Bambu de corpo e alma, Canal6, Bauru, SP, Brasil, 2007.

[35] W. Zhaohui, W. Zehui, R. Xigen, Studies on radial variation in density of Moso Bamboo using X-ray scanning, Sci. Silvae Sin. 40 (3) (2004) 111-116.

[36] A. Shatalov, H. Pereira, Papermaking fibers from Giant Reed (Arundo donax L.) by advanced ecologically friendly pulping and bleaching technologies, Bioresources 1 (1) (2006) 45-61.

[37] W. Quirino, I. Valle de Oliveira, A. Cezar de Oliveira, F. de Souza, M. Tomazello, Densitometria de raios x na análise da qualidade de briquetes de resíduos de madeira: X ray densitometry for waste wood briquetts analysis, Sci. For. 40 (96) (2012) 525-536.

[38] Á. Ramírez-Gómez, E. Gallego, J. Fuentes, C. González-Montellano, F. Ayuga, Values for particle-scale properties of biomass briquettes made from agroforestry residues, Particuology 602 (2013) 7. 